\title{
A NEW ROBUST ANALYTICAL METHOD DEVELOPMENT AND VALIDATION FOR SIMULTANEOUS ESTIMATION OF RIBOCICLIB AND LETROZOLE IN SOLID DOSAGE FORM (TABLET)
}

\author{
BHAGYALATA SATAPATHY ${ }^{1 *}$, CHAITANYA BANGARI ${ }^{2}$
}

Avanthi Institute of Pharmaceutical Science, Visakhapatnam, India. Email: bhagyalata.satapathy22@gmail.com

Received: 19 March 2021, Revised and Accepted: 05 October 2021

\section{ABSTRACT}

Objective: The objective of the study was to develop a new robust, sensitive, precise, accurate RP-HPLC analytical method and validate for simultaneous estimation of ribociclib and letrozole in solid dosage form (tablet).

Methods: The chromatographic separation was carried out on Waters, symmetry C18 (150 mm×4.6 mm with $3.5 \mu \mathrm{m})$, mobile phase used was a mixture of buffer and acetonitrile in the ratio of 80:20, with flow rate of $1 \mathrm{ml} / \mathrm{min}$ and injection volume of $10 \mu \mathrm{L}$ for the assay. The detection was done using PDA at $260 \mathrm{~nm}$, with run time of $5 \mathrm{~min}$. The retention time for the drugs ribociclib and letrozole was detected to be $2.648 \mathrm{~min}$ and $3.151 \mathrm{~min}$, respectively. The method was validated according to ICH guidelines.

Results: The linearity of letrozole and ribociclib was observed to be in the range of $0.50-7.50$ and $40.01-600.15$, Correlation coefficient $\left(\mathrm{r}^{2}\right) 0.999$ and 0.9983 , respectively. Accuracy for ribociclib and letrozole is carried out by repeatable concentrations of $50 \%, 100 \%$, and 150 . Validation factors of robustness and ruggedness were detected to be in limits.

Conclusion: The developed method was simple, rapid, and consistent; it can be used for the simultaneous estimation of ribociclib and letrozole tablet dosage form in routine analysis.

Keywords: RP-HPLC, Ribociclib, Letrozole, Method validation and simultaneous estimation.

(C) 2021 The Authors. Published by Innovare Academic Sciences Pvt Ltd. This is an open access article under the CC BY license (http://creativecommons.org/ licenses/by/4.0/) DOI: http://dx.doi.org/10.22159/ajpcr.2021v14i11.41511. Journal homepage: https://innovareacademics.in/journals/index.php/ajpcr

\section{INTRODUCTION}

Chemically ribociclib is 7-cyclopentyl-N, N-dimethyl-2-\{[5(1-piperazinyl)-2-pyridinyl] amino\}-7H- pyrrolo[2,3-d] pyrimidine- 6-carboxamide (Fig.1). Slight yellow to brown. It is freely soluble in dichloromethane; slightly soluble in ethanol; practically insoluble in water. Ribociclib holds cyclin-dependent kinase4 and 6(CDk4/6) inhibitor2 helps to slow the progression of cancer [1-3]. The drug regulates cell cycle progression through phosphorylation of the retinoblastoma protein $(\mathrm{pRb})$. The combination of ribociclib with anti-estrogen results in increased inhibition of tumor growth. $200 \mathrm{mg}$ tablets of the drug are available for oral administration.

Chemically letrozole is 4,4-((1H-1,2,4-triazole-1-yl) methylene) dibenzo nitrile [4], orally active, nonsteroidal selective aromatase inhibitor, used for the treatment of postmenopausal women with breast cancer and being an antiestrogen [5]. Letrozole is soluble in organic solvents such as dimethyl sulfoxide (DMSO) and dimethyl formamide (DMF), which should be purged with an inert gas. The solubility of letrozole in these solvents is approximately $16 \mathrm{mg} / \mathrm{ml}$, sparingly soluble in aqueous buffers [4]. It acts by irreversible binding to the heme of its cytochrome P450 unit. The action is distinct and does not reduce secretion of corticosteroids. Letrozole is considered as equally effective as ovariectomy in reducing uterine weight, by increasing serum LH and causing the retrogression of estrogen dependent tumors. As compared to ovariectomy treatment with letrozole will not cause in the level of serum FSH.

Survey of literature revealed that various RP-HPLC analytical methods were available for the determination of letrozole in combination with vilazodone/palbociclib and also for the determination of ribociclib individually or in combination with palbociclib [2]. Hence, an attempt was made to develop a simple, rapid, and validated method for the simultaneous estimation of ribociclib and letrozole in combination tablet dosage form.

\section{METHODS}

Chemicals and reagents

Acetonitrile (HPLC grade), Ortho Phosphoric Acid (HPLC grade), HPLC grade, Water (Milli Q or equivalent)

\section{Instrumentation and chromatographic condition}

Separation was carried out using the column Waters, Symmetry C18, $150 \mathrm{~mm} \times 4.6 \mathrm{~mm}, 3.5 \mu \mathrm{m}$, with mobile phase Acetonitrile: Ortho Phosphoric Acid Buffer in ratio 20:80, was degassed and filtered by using $0.45 \mu \mathrm{m}$ membrane filter in a vacuum filter system. Separation was carried out at room temperature by injecting $10 \mu \mathrm{l}$ with flow rate $1.0 \mathrm{ml} / \mathrm{min}$. The analytes were quantified with PDA detector at $260 \mathrm{~nm}$.

\section{Preparation of solutions}

Buffer $1 \mathrm{ml}$ of O-phosphoric acid buffer dissolved in $1 \mathrm{~L}$ of HPLC water.

Diluent mobile phase used as diluent.

\section{Standard solution}

$400 \mathrm{mg}$ of ribociclib and $5 \mathrm{mg}$ of letrozole working standards were taken into a $100 \mathrm{ml}$ volumetric flask, $70 \mathrm{ml}$ of diluents was added and sonicated for $15 \mathrm{~min}$ to dissolve the contents, the final volume was made with diluent. $5 \mathrm{ml}$ of above solution was pipetted out and diluted to $50 \mathrm{ml}$ with diluent.

\section{Preparation of sample solution}

Average weight of five tablet taken, then three tablets were powered into power form, $500 \mathrm{mg}$ of powder was taken in a $100 \mathrm{ml}$ volumetric flask, $70 \mathrm{ml}$ of diluent was added and sonicated for $30 \mathrm{~min}$ to dissolve 


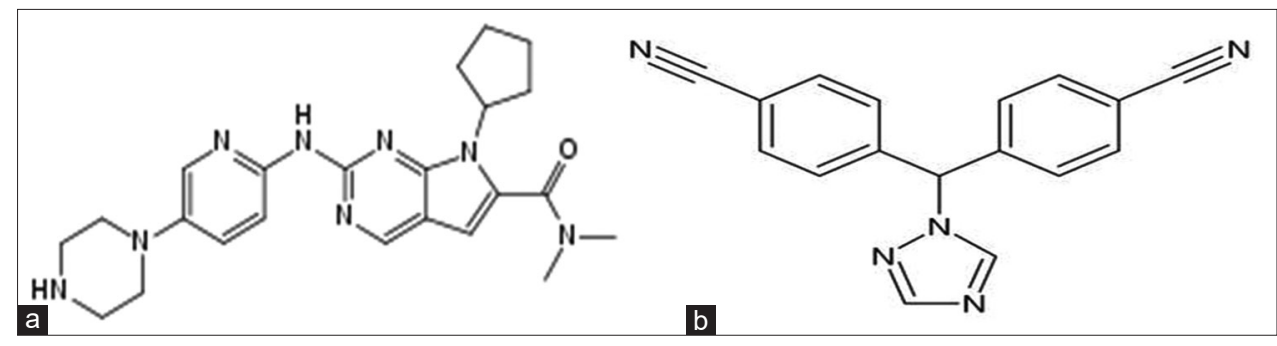

Fig. 1: (a) Ribociclib, (b) Letrozole

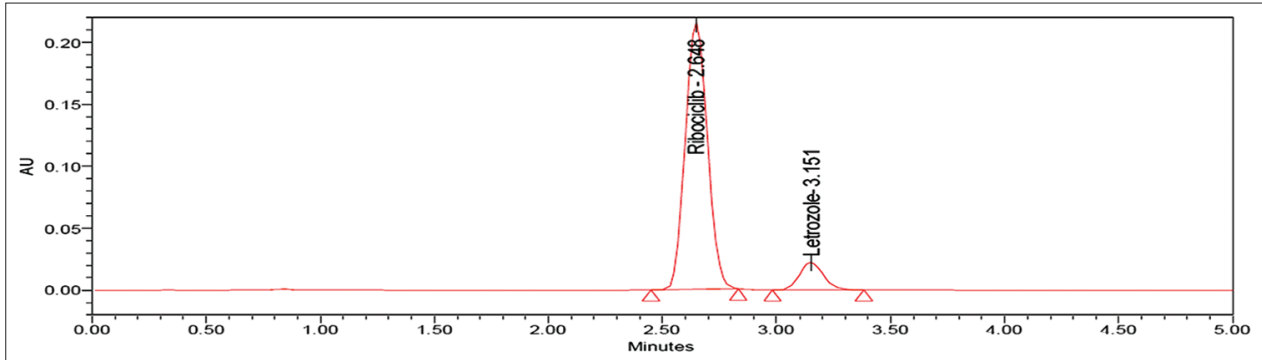

Fig. 2: Optimized chromatogram. Retention time of ribociclib is about $2.648 \mathrm{~min}$. Retention time of letrozole is about $3.151 \mathrm{~min}$

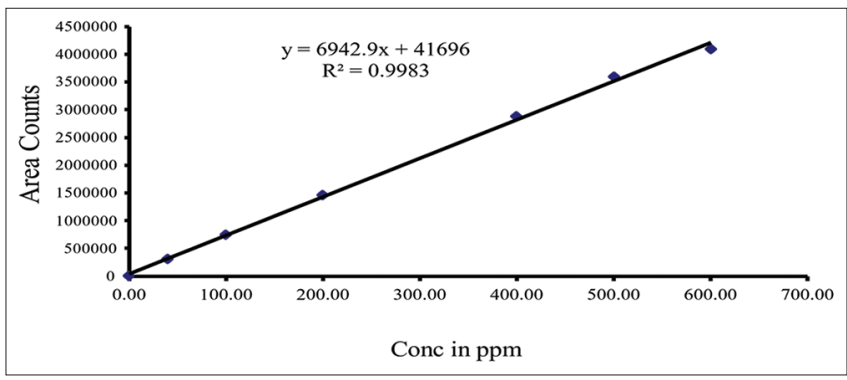

Fig. 3: Linear plot for ribociclib

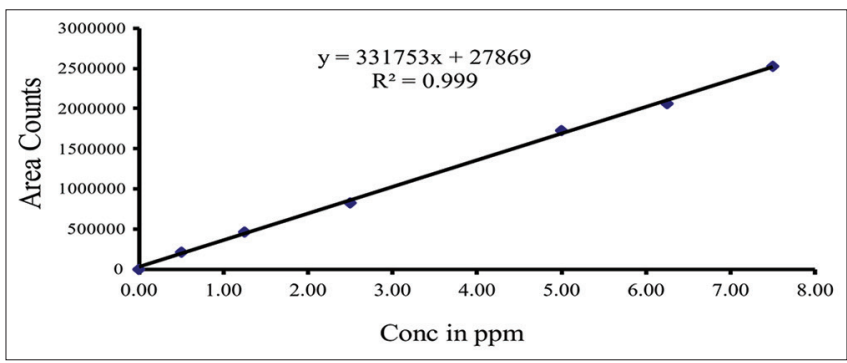

Fig. 4: Linear plot for letrozole

Table 1: Working standard for letrozole

\begin{tabular}{llll}
\hline Std. Name & Letrozole & \% Potency & $\mathbf{1 0 0 . 0}$ \\
\hline STD wt. (mg) & 5.00 & & \\
Dilutions & Wt taken in mg into $100 \mathrm{~mL}$ & Concentration & 50 \\
& $5 \mathrm{~mL} 50 \mathrm{~mL}$ & (ppm) & 5 \\
& $1 \mathrm{~mL} 1 \mathrm{~mL}$ & & 5 \\
\hline
\end{tabular}

Table 2: Working standard for ribociclib

\begin{tabular}{llll}
\hline Std. Name & Ribociclib & \% Potency & $\mathbf{1 0 0 . 0}$ \\
\hline STD wt. (mg) & 400.10 & & \\
Dilutions & Wt taken in mg into $100 \mathrm{~mL}$ & Concentration & 4001 \\
& $5 \mathrm{~mL} 50 \mathrm{~mL}$ & (ppm) & 400.1 \\
& $1 \mathrm{~mL} 1 \mathrm{~mL}$ & & 400.1 \\
\hline
\end{tabular}

the contents completely. $5 \mathrm{ml}$ of above solution was pipette out and diluted to $50 \mathrm{ml}$ with diluent.

\section{Procedure for assay}

Six replicates of standard and sample were analyzed. $10 \mu \mathrm{l}$ of blank, standard solution and sample solution was injected into the HPLC system. From the peak area of the chromatogram, the percentage purity of the sample was calculated.

\section{Method validation}

The optimized chromatographic condition is applied for quantitative determination and the method was validated by considering some parameters linearity, precision, accuracy (\% recovery), robustness, system precision, method precision, and ruggedness $[5,6]$.

\section{Specificity}

The specificity of an analytical method is its ability to quantify with precision and especially the analyte of interest in the presence of other components that are likely to be present in the sample. The blank, standard, sample, and placebo solutions were injected to check the interference.

\section{Linearity}

It is the ability of the method to produce the test results which are directly proportional to the concentration of analyte in the sample solution. Six concentrations for the drugs letrozole and ribociclib at $0.50,1.25,2.50,5,6.25$, and $7.50 \mu \mathrm{g} / \mathrm{mL}$ and $40.01,100.03,200.05$, $400.10,500.13$, and $600.15 \mu \mathrm{g} / \mathrm{mL}$, respectively, were prepared from the standard solution and $10 \mu \mathrm{l}$ of each was injected.

\section{Accuracy}

The accuracy of an analytical method is the proximity of the test results derived by that method to the true value. This is sometimes termed trueness. It is proposed that accuracy should be determined using not less than nine determinations over a minimum of the three concentration levels, covering the specified range (three concentrations/three replicates each of total analytical procedures). Accuracy was studied using the standard addition method. For letrozole recovery studies, $2.5 \mathrm{mg}$ of standard was added for $50 \%, 5 \mathrm{mg}$ was added for $100 \%$, and $7.5 \mathrm{mg}$ was added for $150 \%$, for ribociclib, $200 \mathrm{mg}$ was added for $50 \%$, $400 \mathrm{mg}$ was added for $100 \%$, and $600 \mathrm{mg}$ for $150 \%$ was added to the previously prepared test solutions. 
Table 3: Linearity for ribociclib and letrozole

\begin{tabular}{|c|c|c|c|c|c|c|c|}
\hline \multicolumn{4}{|l|}{ Ribociclib } & \multicolumn{4}{|l|}{ Letrozole } \\
\hline mL of lin stock & Vol. made up to & $\mu \mathrm{g} / \mathrm{mL}$ & Area count & mL of Lin stock & Vol made upto & $\mu \mathrm{g} / \mathrm{mL}$ & Area count \\
\hline 0 & 0 & 0.00 & 0 & 0 & 0 & 0.00 & 0 \\
\hline 1.25 & 50 & 100.03 & 739150 & 1.25 & 50 & 1.25 & 464156 \\
\hline 2.5 & 50 & 200.05 & 1461298 & 2.5 & 50 & 2.50 & 832584 \\
\hline 5 & 50 & 400.10 & 2880851 & 5 & 50 & 5.00 & 1726321 \\
\hline 6.25 & 50 & 500.13 & 3596077 & 6.25 & 50 & 6.25 & 2062896 \\
\hline \multirow[t]{4}{*}{7.5} & 50 & 600.15 & 4089562 & 7.5 & 50 & 7.50 & 2524821 \\
\hline & Correl Coeff. & & 0.99915 & Correl Coeff. & 0.99953 & 0.99953 & 0.99953 \\
\hline & Slope & & 6942.87 & Slope & 331753.49 & 331753.49 & 331753.49 \\
\hline & Intercept & & 41695.91 & Intercept & 27868.66 & 27868.66 & 27868.66 \\
\hline
\end{tabular}

Table 4: For letrozole



*SD: Standard deviation, *\% RSD: \% relative standard deviation

Table 5: For ribociclib

\begin{tabular}{|c|c|c|c|c|c|c|c|c|}
\hline \multicolumn{9}{|l|}{ Ribociclib } \\
\hline & \multicolumn{2}{|l|}{ Batch no } & \multirow{3}{*}{$\begin{array}{l}\text { Area Counts } \\
\text { Injection }\end{array}$} & \multicolumn{2}{|c|}{ Potency (As is basis) } & \multirow{3}{*}{$\begin{array}{l}100.0 \\
\% \text { Recovery }\end{array}$} & & \\
\hline & \multirow{2}{*}{$\begin{array}{l}\text { Amount of API } \\
\text { Added (mg) }\end{array}$} & \multirow{2}{*}{$\begin{array}{l}\text { Actual API } \\
\text { Added (mg) }\end{array}$} & & \multirow{2}{*}{$\begin{array}{l}\text { Mean } \\
\text { Area Counts }\end{array}$} & \multirow{2}{*}{$\begin{array}{l}\text { Amount } \\
\text { Recovered (mg) }\end{array}$} & & & \\
\hline & & & & & & & & \\
\hline \multirow[t]{2}{*}{$50 \%$ accuracy } & 200 & 200.00 & 1360582 & 1360582 & 197.53 & 98.8 & Mean & 99.1 \\
\hline & 200 & 200.00 & 1364716 & 1364716 & 198.13 & 99.1 & SD & 0.28 \\
\hline \multirow[t]{3}{*}{$100 \%$ accuracy } & 400 & 400.00 & 2744501 & 2744501 & 398.44 & 99.6 & Mean & 99.4 \\
\hline & 400 & 400.00 & 2746991 & 2746991 & 398.8 & 99.7 & SD & 0.50 \\
\hline & 400 & 400.00 & 2721988 & 2721988 & 395.17 & 98.8 & \%RSD & 0.500 \\
\hline \multirow[t]{5}{*}{$150 \%$ accuracy } & 600 & 600.00 & 4071373 & 4071373 & 591.08 & 98.5 & Mean & 98.6 \\
\hline & 600 & 600.00 & 4072024 & 4072024 & 591.17 & 98.5 & SD & 0.22 \\
\hline & 600 & 600.00 & 4087242 & 4087242 & 593.38 & 98.9 & \%RSD & 0.220 \\
\hline & & & & & Mean & 99.0 & & \\
\hline & & & & & SD & 0.404 & & \\
\hline
\end{tabular}

*SD: Standard deviation, *\% RSD: \% relative standard deviation

\section{Precision}

The precision of an analytical method is the degree of agreement among individual test results when the method is recurrent to multiple samplings of samples that are not homogenous in nature.

\section{System precision}

Six replicates of standard solution of both the drug were analyzed by the same analyst, on the same equipment on the same day. Area of the peak and \% RSD were calculated.

\section{Method precision}

Six different standard solutions for both the drug were prepared from homogenous sample solution and were analyzed by the same analyst, on the same equipment on the same day. The assay results and \% RSD were calculated.

Robustness

The robustness determines the influence of small but steady variation in the chromatographic conditions. The robustness of the method was 
Table 6: For working standards

\begin{tabular}{|c|c|c|c|c|}
\hline Working standard & \multicolumn{2}{|c|}{ Letrozole } & Dilutions & ppm \\
\hline Wt. taken (mg) & \multicolumn{2}{|l|}{5} & Taken in to $100 \mathrm{ml}$ & 50.0 \\
\hline \% Potency & 100.0 & $\begin{array}{l}\mathrm{w} / \mathrm{w} \\
\text { (as is } \\
\text { basis) }\end{array}$ & $1 \mathrm{ml}$ to $1 \mathrm{ml}$ & 5.0 \\
\hline Working standard & \multicolumn{2}{|c|}{ Ribociclib } & Dilutions & ppm \\
\hline Wt. taken (mg) & \multirow{2}{*}{\multicolumn{2}{|c|}{400.1}} & Taken in to $100 \mathrm{ml}$ & 4001.0 \\
\hline B. No & & & $5 \mathrm{ml}$ to $50 \mathrm{ml}$ & 400.1 \\
\hline \% Potency & 100.0 & $\begin{array}{l}\mathrm{w} / \mathrm{w} \\
\text { (as is } \\
\text { basis) }\end{array}$ & $1 \mathrm{ml}$ to $1 \mathrm{ml}$ & 400.10 \\
\hline
\end{tabular}

Table 7: For system precision

\begin{tabular}{|c|c|c|}
\hline \multicolumn{2}{|l|}{ Ribociclib } & \multirow{2}{*}{$\begin{array}{l}\text { Letrozole } \\
\text { Standard area counts }\end{array}$} \\
\hline \multicolumn{2}{|c|}{ Standard area counts } & \\
\hline Injection & Area & Area \\
\hline 1 & 2760981 & 309393 \\
\hline 2 & 2757098 & 308271 \\
\hline 3 & 2751049 & 307449 \\
\hline 4 & 2752301 & 308183 \\
\hline 5 & 2760385 & 307998 \\
\hline 6 & 2753672 & 306959 \\
\hline Mean & 2755914 & 308042 \\
\hline SD & 4214.61 & 827.53 \\
\hline \% RSD & 0.153 & 0.269 \\
\hline
\end{tabular}

*SD: Standard deviation, $* \%$ RSD: \% relative standard deviation determined by changing the flow rate $\left(0.9\right.$ and $\left.1.1 \mathrm{mLmin} \_1\right)$ of the mobile phase, $\mathrm{pH}$ of ortho phosphate buffer, ratio of composition of the mobile phase and wavelength.

Limit of detection and limit of quantitation

Limit of detection is the lowest amount of sample detected by an analytical procedure but not quantified exactly. Limit of quantitation is the lowest amount of sample that can be quantified by an analytical procedure.

As per ICH guidelines, in the simultaneous analytical method development study, limit of detection and limit of quantitation were based on the standard deviation of the response and slopes using signal-to-noise ratio.

\section{RESULTS AND DISCUSSION}

Several trials have been performed for the development of the method by changing the column, flow rate, mobile phase ratio, and wavelength.

The chromatogram of optimized method is shown in Fig. 2.

Optimized trials

Optimized chromatographic condition

\begin{tabular}{ll}
\hline Parameters & Optimized conditions \\
\hline $\begin{array}{l}\text { Mobile phase ratio } \\
\text { Column }\end{array}$ & $\begin{array}{l}\text { Acetonitrile and ortho phosphoric acid (20:80) } \\
\text { Waters, symmetry C18, 150 mm×4.6 mm, 3.5 } \\
\mu \mathrm{m}\end{array}$ \\
Flow rate & $1.0 \mathrm{ml} / \mathrm{min}$ \\
Wavelength & $260 \mathrm{~nm}$ \\
Injection Volume & $10 \mu \mathrm{L}$ \\
Elution mode & Isocratic \\
Run time & $5 \mathrm{~min}$ \\
Column & $25^{\circ} \mathrm{C}$ \\
temperature & \\
\hline
\end{tabular}

Table 8: Method precision for ribociclib

\section{Ribociclib}

\section{Standard area counts}

\begin{tabular}{|c|c|c|c|c|c|c|}
\hline & \\
\hline Injection & Area & Brack. Std. & $\begin{array}{l}\text { Sample } \\
\text { weight (mg) }\end{array}$ & $\begin{array}{l}\text { Area counts } \\
\text { injection }\end{array}$ & $\begin{array}{l}\text { Mean area } \\
\text { counts }\end{array}$ & $\begin{array}{l}\text { \% Label } \\
\text { claim }\end{array}$ \\
\hline 1 & 2760981 & 2748621 & 500.2 & 2747629 & 2747629 & 99.7 \\
\hline 2 & 2757098 & & 500.4 & 2711616 & 2711616 & 98.3 \\
\hline 3 & 2751049 & & 500.2 & 2716991 & 2716991 & 98.6 \\
\hline 4 & 2752301 & & 500.1 & 2730071 & 2730071 & 99.1 \\
\hline 5 & 2760385 & & 500.4 & 2754107 & 2754107 & 99.9 \\
\hline 6 & 2753672 & & 500.3 & 2773887 & 2773887 & 100.6 \\
\hline SD & 4214.61 & 4733.01 & & & SD & 0.862 \\
\hline$\%$ RSD & 0.153 & 0.172 & & & $\%$ RSD & 0.87 \\
\hline
\end{tabular}

*SD: Standard deviation, *\% RSD: \% relative standard deviation

Table 9: Method precision for letrozole

\begin{tabular}{|c|c|c|c|c|c|c|}
\hline \multicolumn{7}{|l|}{ Letrozole } \\
\hline \multicolumn{3}{|c|}{ Standard area counts } & \multicolumn{4}{|l|}{ Sample area counts } \\
\hline Injection & Area & Brack. Std. & Sample weight (mg) & Area counts injection & Mean area counts & $\%$ label claim \\
\hline 1 & 309393 & 304867 & 500.2 & 305295 & 305295 & 99.0 \\
\hline 2 & 308271 & & 500.4 & 305997 & 305997 & 99.2 \\
\hline 3 & 307449 & & 500.2 & 309917 & 309917 & 100.5 \\
\hline 4 & 308183 & & 500.1 & 307131 & 307131 & 99.6 \\
\hline Mean & 308259 & 307694 & 500.3 & 308831 & 308831 & 100.1 \\
\hline SD & 709.95 & 1523.35 & & & Mean & 99.5 \\
\hline \multirow[t]{2}{*}{$\%$ RSD } & 0.23 & 0.495 & & & $\mathrm{SD}$ & 0.763 \\
\hline & & & & & $\%$ RSD & 0.77 \\
\hline
\end{tabular}

*SD: Standard deviation, *\% RSD: \% relative standard deviation 
Table 10: Limit of detection (LOD)

\begin{tabular}{|c|c|c|c|c|c|c|c|c|}
\hline Sample name & Sample concentration & Retention Time & Area $\left(\mu V^{*} s e c\right)$ & $\%$ Area & USP tailing & $\mathbf{s} / \mathbf{n}$ & USP plate count & USP resolution \\
\hline Ribociclib & 0.4001 & 2.639 & 17081 & 71.29 & 1.09 & 7 & 3179 & \\
\hline Letrozole & 0.005 & 3.140 & 2630 & 28.71 & 1.15 & 5 & 3839 & 2.52 \\
\hline
\end{tabular}

Table 11: Limit of quantitation

\begin{tabular}{|c|c|c|c|c|c|c|c|c|}
\hline Sample name & Sample concentration & Retention Time & Area $\left(\mu V^{*} s e c\right)$ & $\%$ area & USP tailing & $\mathbf{s} / \mathbf{n}$ & USP plate count & USP resolution \\
\hline Ribociclib & 4.005 & 2.629 & 302070 & 90.69 & 1.09 & 27 & 3095 & \\
\hline Letrozole & 0.05 & 3.131 & 31002 & 9.31 & 1.10 & 22 & 3980 & 2.58 \\
\hline
\end{tabular}

Table 12: For letrozole

\begin{tabular}{|c|c|c|c|c|c|c|}
\hline Variation & $\begin{array}{l}\text { Standard } \\
\text { mean area }\end{array}$ & $\begin{array}{l}\text { SD of } \\
\text { Standard }\end{array}$ & $\begin{array}{l}\text { RSD of } \\
\text { Standard }\end{array}$ & $\begin{array}{l}\text { Mean \%label } \\
\text { claim of sample }\end{array}$ & $\begin{array}{l}\text { SD \%label } \\
\text { claim of sample }\end{array}$ & $\begin{array}{l}\text { RSD \%label } \\
\text { claim of sample }\end{array}$ \\
\hline Flow plus & 288126 & 5001.4 & 1.736 & 100.7 & 0.058 & 0.06 \\
\hline Flow minus & 371291 & 4037.32 & 1.08 & 99.9 & 0.3 & 0.3 \\
\hline Org plus & 313139 & 3702.98 & 1.183 & 99.5 & 0.265 & 0.27 \\
\hline Org minus & 344854 & 2773.86 & 0.804 & 99.6 & 0.361 & 0.36 \\
\hline pH plus & 284983 & 2683.53 & 0.926 & 99.4 & 0.681 & 0.69 \\
\hline pH minus & 346080 & 3405.23 & 0.984 & 99.8 & 0.954 & 0.96 \\
\hline Wave minus & 325860 & 673.78 & 0.207 & 99.6 & 0.889 & 0.89 \\
\hline
\end{tabular}

Table 13: For ribociclib

\begin{tabular}{|c|c|c|c|c|c|c|}
\hline Variation & $\begin{array}{l}\text { Standard mean } \\
\text { area }\end{array}$ & $\begin{array}{l}\text { SD of } \\
\text { Standard }\end{array}$ & $\begin{array}{l}\text { RSD of } \\
\text { standard }\end{array}$ & $\begin{array}{l}\text { Mean \%label } \\
\text { claim of sample }\end{array}$ & $\begin{array}{l}\text { SD \%label claim } \\
\text { of sample }\end{array}$ & $\begin{array}{l}\text { RSD \%label claim } \\
\text { of sample }\end{array}$ \\
\hline Flow plus & 2528147 & 16839.14 & 0.666 & 99.9 & 0.586 & 0.59 \\
\hline Flow minus & 3331018 & 18882.69 & 0.567 & 100.2 & 0.503 & 0.5 \\
\hline Org plus & 2769764 & 13196.04 & 0.476 & 99.7 & 0.929 & 0.93 \\
\hline Org minus & 2909548 & 9672.9 & 0.332 & 100.3 & 0.306 & 0.31 \\
\hline pH plus & 2532149 & 14183.74 & 0.56 & 100.2 & 0.208 & 0.21 \\
\hline $\mathrm{pH}$ minus & 3348280 & 24029.87 & 0.718 & 100 & 0.2 & 0.2 \\
\hline Wave minus & 3328400 & 3245 & 0.097 & 99.9 & 0.058 & 0.06 \\
\hline
\end{tabular}

\section{Validation of proposed method}

Linearity

Linear correlation was prevailed between peak area versus concentration of letrozole and ribociclib. Calibration curves were linear in the concentration range from $0.50 \mu \mathrm{g} / \mathrm{mL}$ and $7.50 \mu \mathrm{g} / \mathrm{mL}$ for letrozole and $40.01 \mu \mathrm{g} / \mathrm{mL}$ and $600.15 \mu \mathrm{g} / \mathrm{mL}$ for ribociclib. Linearity of the calibration curves was validated from the value of correlation coefficients of the regression analysis. The value of $\mathrm{r}^{2}$ was 0.99953 for letrozole and 0.9983 for ribociclib. The results of the linearity experiment are listed in Tables 1-3 and the calibration plot is given in Figs. 3 and 4 for ribociclib and letrozole, respectively.

\section{Accuracy}

The experiments were performed in accordance to standard addition method. The percentage recovery and \% RSD were calculated for both ribociclib and letrozole. The \% RSD was found to be within limit (Tables 4 and 5).

\section{Precision}

System precision: Six injections of standard solutions of both the drugs were injected. The results are listed in the Tables 6 and 7.

\section{Method precision}

Method precision determined with developed method $(n=6)$.

The precision of the method was given in the Tables 8-11.
Limit of detection (LOD) and limit of quantitation (LOQ)

The limit of detection for letrozole and ribociclib was found to be 0.005 and $0.4001 \mu \mathrm{g} / \mathrm{mL}$, while the limit of quantitation for letrozole and ribociclib was found to be 0.05 and $4.005 \mu \mathrm{g} / \mathrm{mL}$, respectively.

\section{Robustness}

The intend changes in the method do not have more impact in the peak tailing, theoretical plates, and the percent assay of letrozole and ribociclib. It has been performed by changing the composition of the mobile phase, flow rate, wave, and pH of buffer (Tables 12 and 13).

\section{CONCLUSION}

The suggested RP-HPLC method was rapid, more precise, robust, and sensitive. This RP-HPLC method accommodates the utilization of the economically and simply available mobile phase and PDA detector. The validated method can be used for the routine analysis of both the drugs from bulk and different formulations and will help in therapeutic drug monitoring (TDM) and bioavailability studies.

\section{ACKNOWLEDGMENT}

The authors would like to thank the management of Avanthi Institute of Pharmaceutical Science, Visakhapatnam for providing the necessary facilities and funding to carry out of this research work. The authors are grateful to ICON labs, Hyderabad for providing a gift sample of the drug and other facilities too. 


\section{CONFLICT OF INTERESTS}

Declared none.

\section{REFERENCES}

1. Kala A, Patel YT, Davis A, Stewart CF. Development and validation of LC-MS/MS methods for the measurement of ribociclib, a CDK4/6 inhibitor, in mouse plasma and Ringer's solution and its application to a cerebral microdialysis study. J Chromatogr B Analyt Technol Biomed Life Sci 2017;1057:110-7.

2. Sreelakshmi M, Sasidhar RL, Raviteja B. Simultaneous estimation of ribociclib and palbociclib in bulk samples by reverse phase high performance liquid chromatography. Int J Pharm Biol Sci 2019;9:413-21.

3. Bao X, Wu J, Sanai N, Li J. Determination of total and unbound ribociclib in human plasma and brain tumor tissues using liquid chromatography coupled with tandem mass spectrometry. J Pharm Biomed Anal 2019;166:197-204

4. Kaplan C, Ünal S. A Validated Method without Derivatization for the Determination of Letrozole by High Performance Liquid Chromatography-Fluorimetric Method for Pharmaceutical Preparation. Turkey: Istanbul University Press; 2018. p. 38-42.

5. Mondal N, Pal TK, Ghosal SK. Development and validation of RP-HPLC method to determine letrozole in different pharmaceutical formulations and its application to studies of drug release from nanoparticles. Acta Pol Pharm 2009;66:11-7.

6. Dange Y, Bhinge S, Salunkhe V. Optimization and validation of RP-HPLC method for simultaneous estimation of palbociclib and letrozole. Toxicol Mech Methods 2018;28:187-94. 